\title{
The Application of Chinese Excellent Traditional Culture in College Students' Ideological and Political Education
}

\author{
Lisheng Liao \\ The School of Marxism, South China University of Technology, China. \\ 489412332@qq.com
}

\begin{abstract}
Keywords: college students, Chinese excellent traditional culture, integration, ideological and political education, campus culture.
\end{abstract}

\begin{abstract}
In order to improve the level of ideological and political education in colleges and universities, Chinese excellent traditional culture was applied in the education. First of all, the connotation of Chinese excellent traditional culture was elaborated. On this basis, the significance of Chinese excellent traditional culture in the ideological and political education of college students was discussed. Then, based on the questionnaire survey of 9 college students in Guangzhou, the current situation, characteristics and reasons of the lack of Chinese excellent traditional culture in today's college students' ideological and political quality were analyzed. Finally, to integrate the traditional culture into the ideological and political education of college students, the corresponding strategic measures were put forward. The results showed that Chinese excellent traditional culture enhanced the effectiveness of ideological and political education of college students. To sum up, it is of great significance to integrate Chinese traditional culture into the ideological and political education of college students. The excellent traditional culture improves the ideological and moral quality of college students.
\end{abstract}

\section{Introduction}

Chinese traditional culture has a long history. In the accumulation and precipitation of thousands of years, a distinctive cultural system has been formed [1-2]. Chinese excellent traditional culture should be integrated into curriculum and teaching material system, so as to promote the close integration of ideological and political education and Chinese excellent traditional culture education. It points out the direction of strengthening the ideological and political education of college students [3]. The culture of a nation embodies the nation's cognition and reality of the world and its own development history and accumulates the deepest spiritual pursuit and value criterion of the nation. If China wants to develop and prosperity, it is necessary to carry forward the fine traditional culture and cultivate a high spirited national spirit [4].

College students are the hope of the nation. Chinese excellent traditional culture contains rich content of ideological and political education, so it is an inexhaustible valuable resource for ideological and political education of college students. Ideological and political education workers should be good at exploring and using the connotation of these excellent traditional culture and integrate into the ideological and political course. Through the inheritance and infiltration of culture, college students get a good ideological and moral education, personality quality education and ideal sentiment education, so as to better improve the humanities of college students.

\section{State of the Art}

Qu Jiangbin and Zhang Wei believe that under the background of economic and cultural globalization, strengthening the ideological and political education of college students is an urgent task for colleges and universities [5]. Yan Sue believes that Chinese traditional culture is the crystallization of the wisdom of the Chinese nation, and it is of great significance to improve the ideological and moral quality of college students. As a spiritual carrier of a country, the traditional 
culture is an indispensable part of the development of a nation. The excellent culture of the Chinese nation includes traditional culture and modern civilization. It is not only an important ideological resource to develop Marx doctrine, but also an inexhaustible and inexhaustible source of ideological and political education in the new period.

At present, the ideological and political education of college students is not enough initiative and pertinence, and the carrier is relatively simple [6]. With the rapid development of economy and the invasion of western thoughts, extreme individualism and money worship values have a certain effect on the ideological and political education in colleges and universities. Under the background of economic globalization and cultural diversity, Chinese traditional culture provides rich historical and cultural quality for ideological and political education in colleges and universities in the new period. Because of the realistic needs of racial conflict and racial integration, the education and research of traditional culture by foreign scholars pay more attention to the inheritance and innovation of national tradition and ethnic culture [7].

The traditional culture education research pays great attention to the multicultural education research and forms the practical method of great significance. Drawing on these models, it helps to enhance the effectiveness of traditional culture into the ideological and political education in colleges and universities. The combination of ideological and political education and traditional Chinese culture is not only the requirement of the development of ideological and political education, but also the need of ideological and political education environment construction [8]. Based on China's national conditions, the ideas and methods with Chinese characteristics is established.

\section{Methods and Results}

\subsection{Contents and Methods of Survey}

A total of 20 questions were designed in this questionnaire. The content is mainly about the contemporary college students' understanding, practice and cognition of the Chinese excellent traditional culture. A random survey was conducted among more than 600 college students from 9 universities in Guangzhou.

The survey method mainly uses on-the-spot and online questionnaire survey and on-the-spot discussion. A total of 573 valid questionnaires were collected. Among them, science and engineering students accounted for $47.3 \%$, liberal arts students accounted for $46 \%$. After the investigation, the members of the research group carried out data analysis.

\subsection{Lack of Interest in Traditional Culture}

Through the investigation and analysis of the results, it is found that in some college students' ideological and political quality, the outstanding traditional culture is missing. The results show that more than $90 \%$ of college students recognize the importance of carrying out Chinese excellent traditional culture education. However, as shown in Figure 1, college students are not interested in understanding Chinese traditional culture. $79 \%$ of college students only occasionally read books about Chinese excellent traditional culture. $9 \%$ of college students said they had never read books about Chinese excellent traditional culture. As shown in Figure 2, 73\% of college students have a general understanding of the excellent national spirit and classical humanistic ideas contained in the Chinese traditional culture. Only $12 \%$ of the students expressed a good understanding of traditional culture. The survey of reading Chinese excellent traditional culture books is shown in Figure 1 . The survey of the excellent national spirit and the classic humanistic idea is shown in Figure 2. 


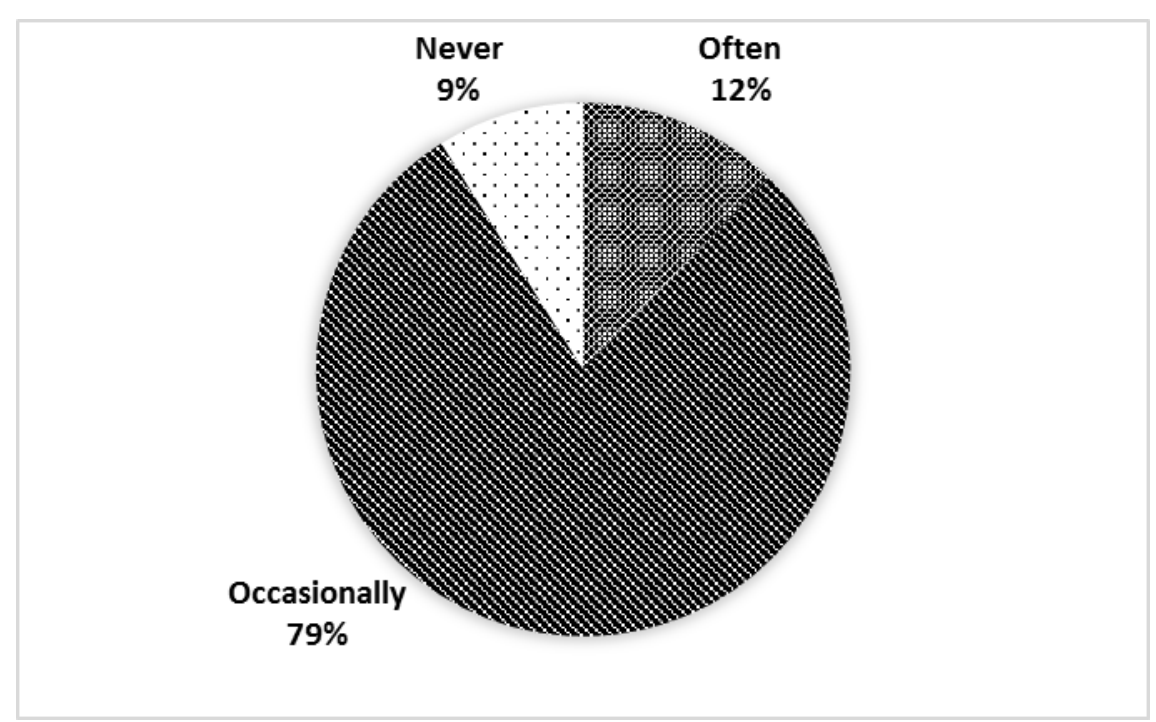

Figure 1. The survey of reading Chinese excellent traditional culture books

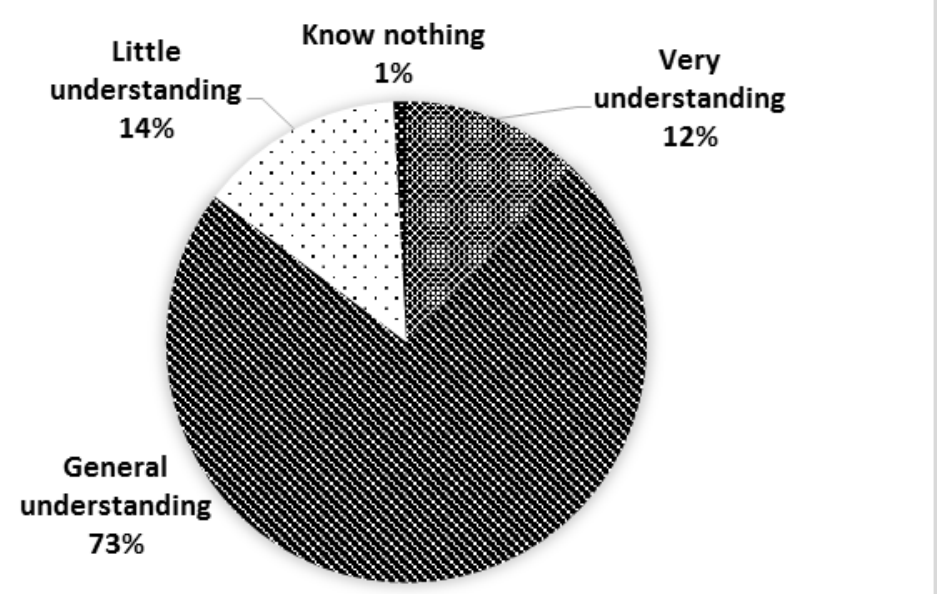

Figure 2. The survey of the excellent national spirit and the classic humanistic idea

Although college students have realized that excellent traditional culture is precious cultural resources, due to the internal and external factors, college students do not pay enough attention to the Chinese traditional culture and lack of interest. The integration of excellent traditional culture into college students' daily life is faced with many difficulties. Traditional culture and ideological and political education are difficult to achieve effective cohesion, so that the traditional culture in the inheritance encountered embarrassment.

\subsection{The Lack of Reform Measures in Classroom Teaching Content}

Classroom teaching is the main way for college students to receive education. It is an important way for the Chinese excellent traditional culture to integrate into the ideological and political education of college students. Some colleges and universities have not yet established a sound ideological and political education system. There is no effective and timely guidance for some ideological and political problems in college students. At the same time, the teaching method is single, and the students have no interest in learning. As shown in Figure 3, 37\% of college students believe that the ideological and political lessons in colleges and universities is very important, it helps students to establish a correct outlook on life, world outlook and values. $63 \%$ of college students think that the content of Ideological and political course is boring and seriously divorced from reality. The survey of the cognition of the ideological and political course in colleges and universities is shown in Figure 3. 


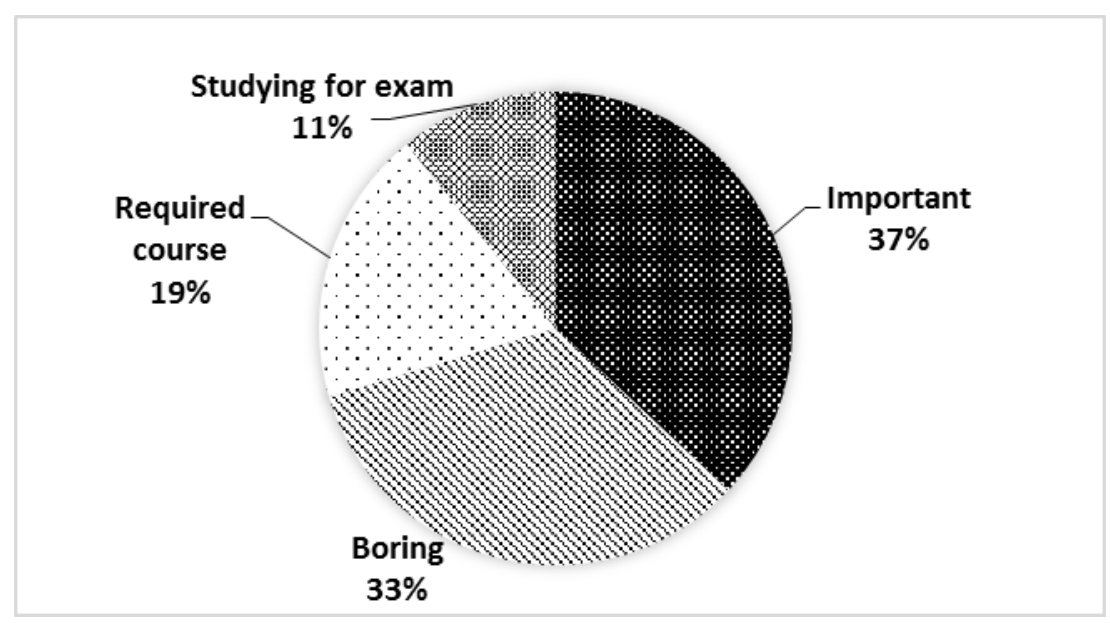

Figure 3. The survey of the cognition of the ideological and political course in colleges and universities

Through the investigation, it is found that some colleges and universities lack the propaganda of the traditional culture in the campus culture, which makes the students not understand the content of the traditional culture. Therefore, the leading role of traditional culture in ideological behavior is not obvious. In the process of traditional cultural education, teachers should be good at playing the function of campus culture. In the classroom, teachers make students often influenced by traditional culture. At the same time, the new media has obvious advantages in spreading culture, carrying forward morality, inheriting civilization and so on. Schools should give full play to the role of the media. Through the use of new media, rich traditional cultural and educational activities are launched. In the entertainment, students feel the charm of traditional culture, and enhance cultural self-confidence.

\section{The Corresponding Measures and Recommendations}

\subsection{The Construction of Excellent Traditional Culture Courses}

Classroom teaching is conducive to the systematic, theoretical and scientific teaching and education of excellent traditional culture. This is one of the most direct, most convenient, and most effective ways for contemporary college students to carry out excellent traditional cultural education. At present, some colleges and universities only offer some public elective courses for outstanding traditional culture. Some colleges and universities have not even set up courses related to excellent traditional culture. This easily leads to the lack of understanding and accumulation of Chinese excellent traditional cultural knowledge among contemporary college students. In order to give full play to the role of classroom teaching, all colleges and universities must set up special courses or elective courses for outstanding traditional culture according to the actual conditions of their respective schools. In the teaching of ideological and political theories in colleges and universities, special courses are arranged to teach university students excellent traditional culture. The scope of required courses for outstanding traditional culture can include ancient philosophical thoughts, appreciation of classical literature, ancient ethics, appreciation of musical paintings, and appreciation of Chinese classical poetry. Through these channels, contemporary college students' knowledge of excellent traditional culture is strengthened, thereby enriching their excellent traditional cultural knowledge system.

The situation and the goal of cultivating college students all require that the ideological and political educators of college students must advance with the times to reform and innovate the teaching content, teaching methods of the excellent traditional culture education. Educators should be able to find and make use of excellent traditional culture to solve the breakthrough points of contemporary college students' focus, hot spots and difficult issues. They are committed to cultivating their sentiments and continuously improving the ability of contemporary college students to judge. In the content of traditional cultural education for college students, all colleges and universities should 
also expand the knowledge system of excellent traditional culture education, increase the amount of outstanding traditional cultural knowledge education for university students, and lay a solid foundation for their excellent traditional cultural knowledge. In terms of teaching methods, excellent traditional culture educators in colleges and universities should make full use of multimedia, Internet, and modern teaching techniques. In a pleasant atmosphere, students' understanding of excellent traditional culture should be improved, and this should lay a good foundation for learning, inheriting, and carrying forward the excellent traditional culture of the nation.

\section{The Establishment of Campus Cultural Platform}

From teachers, teaching, campus material culture, spiritual culture and institutional culture, good school spirit and cultural atmosphere are created. Teachers should have high cultural quality and moral quality. It is necessary to strengthen the construction of the teaching staff of traditional culture education. The overall quality of teachers should be promoted in an all-round way. Classroom teaching is the most important way to carry out ideological and political education in university campus. In order to realize the effective integration of the two, we must reform the teaching content and innovate the teaching method. Excellent traditional culture has been included in the required courses in colleges and universities, and related humanities courses have been set up. Excellent traditional culture has been integrated into the teaching of other subjects, and traditional culture has been infiltrated into professional teaching. Through the network and new media, the traditional culture is further promoted and carried forward, and the moral accomplishment and humanistic quality of college students are enhanced.

In major festivals, thematic education activities should be carried out. For example, on the teachers' day and the Double Ninth Festival, theme celebrations are held to guide college students to carry forward the fine traditional virtues. In Qingming Festival, schools can organize students to go to the revolutionary martyrs' memorial hall, so that students can increase their patriotism. Through a series of rich educational activities, it not only helps to improve students' inner accomplishment, but also lays a good foundation for cultivating students' identity of traditional cultural spirit. Schools can invite famous scholars to carry out lectures on excellent traditional culture knowledge, and recommend classics to guide college students. In the influence of culture, students understand the charm of excellent traditional culture, and then correctly guide the values, ideals and beliefs. Through community activities, traditional culture is presented in many ways. Based on the network multimedia technology, the traditional culture is publicized. With the popularity of the network in college students' learning life, it is necessary to apply it to the whole process of ideological and political education. Therefore, we can make full use of the rich network resources. Through WeChat and blog platforms, excellent Chinese traditional culture has been pushed. On the platform, the teacher can dynamically communicate and guide the students.

\section{The Construction of the Teacher Team}

The teacher is responsible for the cultivation of students' study and ideological and moral character. They should give excellent examples to the students and lead the students to improve their own quality. On the one hand, counselors should improve their understanding of excellent traditional culture. This is the key to the integration of excellent traditional culture into college students' Ideological and political education. Counselor is the main bearer of the ideological and political education of college students. They are accompanied by the various stages of college students' lives, educators who have the most contacts with students and have a wide range of influence on their students. Therefore, in the training of counselors, the content of traditional culture training should be added. On the other hand, teachers should improve their knowledge of traditional culture. Teachers themselves should highly recognize the value of traditional culture, and correctly understand the importance of combining traditional culture with ideological and political education. In the process of 
teaching, teachers should attach importance to traditional culture, carry forward traditional culture, and guide students to learn and understand traditional culture correctly.

Colleges and universities should train a group of excellent teachers in traditional culture and education, and regularly organize teachers to receive training in traditional cultural knowledge, so that they can broaden their horizons and continuously improve their excellent traditional cultural qualities. The colleges and universities must effectively implement the outstanding traditional culture and education of college students. It requires a group of teachers with high professional attainments and deep excellent traditional cultural qualities. They can integrate the excellent traditional culture education into the professional curriculum education and teaching, and can scientifically analyze and interpret the excellent traditional culture. In addition, colleges and universities must also earnestly and responsibly treat the curriculum and arrangement of excellent traditional culture education and teaching, and enhance the enthusiasm, awareness, and initiative of college teachers for outstanding traditional culture education for college students.

\section{Conclusion}

In summary, the integration of excellent traditional culture into college students' ideological and political education is a systematic project. First, it needs policy support and strong guidance from the educational administrative departments. Second, it requires colleges and universities to create a good atmosphere to carry forward the traditional culture. Third, ideological and political workers should constantly innovate the path of integrating the Chinese excellent traditional culture into the ideological and political education of college students. Teachers should play an active role in guiding students, so excellent traditional culture can be inherited and carried forward. In addition to external factors, college students should consciously enhance their own moral cultivation, concerned about the traditional culture, and actively absorb the essence of traditional culture. In particular, college students should cultivate patriotism, and have a strong sense of national pride. At the same time, the school should cultivate students' sense of responsibility to society. Students should earnestly study their expertise and improve their skills in school. By using the emerging media, innovative ideas and thinking are cultivated, so that the ability to recognize things, judge things and solve problems is improved.

\section{References}

[1]. Hua, Z., \& Wei, L. (2014). Geopolitics and the changing hierarchies of the Chinese language: Implications for policy and practice of Chinese language teaching in Britain. The Modern Language Journal, 98(1), 326-339.

[2]. Morris, P., \& Vickers, E. (2015). Schooling, politics and the construction of identity in Hong Kong: the 2012 'Moral and National Education'crisis in historical context. Comparative Education, 51(3), 305-326.

[3]. Solas, C., \& Ayhan, S. (2016). The historical evolution of accounting in China: the effects of culture. De Computis-Revista Española de Historia de la Contabilidad, 4(7), 146-173.

[4]. Wu, S. (2014). The Revival of Confucianism and the CCP's Struggle for Cultural Leadership: a content analysis of the People's Daily, 2000-2009. Journal of Contemporary China, 23(89), 971-991.

[5]. Yan, X. (2014). Engineering stability: authoritarian political control over university students in post-Deng China. The China Quarterly, 218, 493-513.

[6]. Zhang, L. (2014). Bentuhua: Culturing psychotherapy in postsocialist China. Culture, Medicine, and Psychiatry, 38(2), 283-305. 
[7]. Zhu, C., \& Engels, N. (2014). Organizational culture and instructional innovations in higher education: Perceptions and reactions of teachers and students. Educational Management Administration \& Leadership, 42(1), 136-158.

[8]. Zeng, R., \& Greenfield, P. M. (2015). Cultural evolution over the last 40 years in China: Using the Google Ngram Viewer to study implications of social and political change for cultural values. International Journal of Psychology, 50(1), 47-55. 